Modern Asian Studies 55, 3 (202I) pp. 697-733. (C) The Author(s), 2020. Published by

Cambridge University Press. This is an Open Access article, distributed under the terms of the Creative Commons Attribution licence (http://creativecommons.org/licenses/by/4.o/), which permits unrestricted re-use, distribution, and reproduction in any medium, provided the original work is properly cited.

doi:Io.IoI7/Soo26749X20000ı4 First published online 20 July 2020

\title{
Translating and Transliterating Marxism in Indonesia
}

\author{
OLIVER GRAWFORD
}

International Institute for Asian Studies

Email: o.c.crawford@gmail.com

\begin{abstract}
In the I9Ios and I920s, when Indonesian communists first seriously engaged with Marxism, they faced the questions of how to translate Marx's concepts from Dutch, the language in which they generally encountered them, into Malay, the lingua franca of the Indonesian archipelago, and how to make these ideas relevant in an Asian and largely Islamic context. Focusing on three aspects of Marxismthe 'scientific' nature of communism, class conflict in feudal and capitalist society, and the relationship between communism and Islam-I argue that Indonesian communists alternated between transliteration and translation in their exposition of Marxism. Transliterating 'universal' Marxist categories such as proletarian (proletar) and capitalism (kapitalisme) allowed Indonesian communists to speak in global terms and strengthened their claim that Marxism was a science with a universal terminology. At the same time, there was a process of 'localization', whereby foreign Marxist materials were translated to bring them closer to local cultural norms. Malay substitutes were found for Marx's typology of classes and historical eras, while Arabic terms associated with Islam were used to add a moral dimension to the Marxist critique of capitalism. These translations grounded Marxism in Islam and Indonesian history, but also elevated vernacular terms to universal status by eliding them with Marx's categories. The resulting style of Indonesian Marxism was multilingual. From the I930s, however, Indonesian nationalists consciously moved away from transliteration, devising a more thoroughly Indonesian political vocabulary to replace Marx's terms, though one still clearly influenced by Marxism.
\end{abstract}

\section{Introduction}

In his 1945 tract 'Rentjana Ekonomi' ('The Economic Plan'), the Indonesian Marxist and revolutionary Tan Malaka claimed that 'Marx and Engels did not ask, and nor do we allow them, to be worshipped. They would 
be more proud if their theories were well translated [diterjemahkan], according to place and time. ${ }^{1}$ Concerns over translating Marx went back to the earliest days of Indonesian communism. ${ }^{2}$ In the preface to the first Malay-language edition of The Communist Manifesto, published in 1923, the translator, Partondo, admitted that 'the task of translating the writings of Marx is not easy, especially translating from Dutch to Malay, two languages that are extremely different. The translation of this manifesto was even harder for me, because it recounts conditions in Europe, and the words that are used will only with difficulty be translated into Malay. ${ }^{33}$ As this quotation suggests, it was not immediately obvious that Marxism would make any sense in Indonesia. Two difficulties presented themselves: first, the linguistic gap between Dutch, the language in which Indonesians generally encountered Marxism, and Malay, the lingua franca of the Indonesian archipelago; second, the material and cultural gulf between Marx's native Europe and the Dutch East Indies. How could the writings of a nineteenth-century German philosopher be made intelligible in a mainly Islamic, Asian country? In what follows, I will outline how Indonesian communists confronted this problem, exploring their attempts to explain three aspects of Marxism in Malay: first, the 'scientific' nature of communism; second, the character of class conflict in feudal and capitalist society; and third, the relationship between communism and Islam. The chronological focus of this article is the decade-and-a-half between the foundation of the Indische Sociaal-Democratische Vereeniging (Indies Social-Democratic Association, ISDV), the first recognizably socialist organization to be formed in the archipelago, which was begun in Surabaya in I9I4, and the temporary eclipse of Indonesian communism following the failed uprising against the colonial state in $1926-27$, led by

${ }^{1}$ Tan Malaka, 'Rencana Ekonomi', in Tan Malaka, Muslihat, Politik, E̊ Rencana Ekonomi Berjuang (Yogyakarta: Penerbit Narasi, 20I4), pp. I29-235, at p. I44. All translations in this article, unless otherwise stated, are my own. All Malay and Indonesian words are quoted as they appear in the cited sources, which entails switching between pre-independence spellings, the I947-1972 Edjaan Soewandi spelling system, and the post-I972 Ejaan Yang Disempurnakan (EYD) system for sources reprinted after 1972. As a result, the same words are written with 'oe' and 'u', for example, 'goeroe/guru' and 'ilmoe/ilmu', depending on the source. Names are written in the form in which they commonly appear (Sukarno, Semaun, Tjokroaminoto), which span the various systems.

${ }^{2}$ The terms Indonesia and Indonesian are used throughout this article to refer to the territory and inhabitants of the Dutch East Indies. While 'Indonesian' was not in wide circulation until the late I920s, the term 'person from the Indies' is overly cumbersome.

${ }^{3}$ Partondo, Manifest kommunist. Dimelajoeken dan ditambah keterangan oleh Partondo (Semarang: Drukkerij VSTP, I923), p. I. 
the Partai Komunis Indonesia (Indonesian Communist Party, PKI). This period largely overlaps with the 'age in motion' (I9I2-26) identified by Takashi Shiraishi, when a variety of cultural associations, trade unions, and political parties sprang up and began to openly challenge both the colonial government and existing Indonesian world views. ${ }^{4}$ The reception of Marxism was a major reason why the 'age in motion' was so dynamic. Indeed, Marx's influence in this period extended well beyond those officially committed to communism. Nationalists such as Sukarno and Mohammad Hatta engaged extensively with Marx's ideas in the Ig2os, while the leading Islamist Tjokroaminoto felt compelled to explain how the positive elements of socialism were already contained within Islam in his 1924 work Islam dan Sosialisme ('Islam and Socialism'). ${ }^{5}$ The group of Indonesians who were most preoccupied with Marxist thought, however, and whose writings constitute the subject of this article, were the small but dedicated band of communists who, in the course of the igios and I920s, produced the first Malay-language communist newspapers and pamphlets, as well as the first Malay translations of Marx's writings, greatly alarming the colonial government in the process.

The most prolific Indonesian communist author of this period was Tan Malaka, a brilliant, self-trained Marxist from West Sumatra, who had been converted to communism while studying in the Netherlands during the First World War. Between I92I and 1926, he wrote three Malay-language books on communism: Parlement atau Sorjet? ('Parliament or Soviet?', I92I), Toendoek kepada kekoeasaan tetapi tidak kepada kebenaran ('Submission to Might, but not to Right', I922), and Semangat Moeda ('The Young Spirit', I926). ${ }^{6}$ Tan Malaka was among the first

\footnotetext{
${ }^{4}$ Takashi Shiraishi, An Age in Motion: Popular Radicalism in Fava 1912-I926 (Ithaca: Cornell University Press, I990), p. xiv.

${ }^{5}$ See 'Nationalism, Islamism and Marxism', in Soekarno, Under the Banner of Revolution (Jakarta: Publication Committee, I966), Vol. I, pp. I-22; Mohammad Hatta, 'The Economic World Structure and the Conflict of Power', in Mohammad Hatta, Portrait of a Patriot: Selected Writings, Deliar Noer (ed.) (The Hague: Mouton, I972), pp. 36-57; H. O. S. Tjokroaminoto, Islam dan Sosialisme (Jakarta: Lembaga Penggali dan Penghimpun Sedjarah Revolusi Indonesia, I963). This last work was in fact plagiarized from the work by Indian author Mushir Hossain Kidwai, Islam and Socialism (London: Luzac and Co., [1912]). For an illuminating discussion of Tjokroaminoto's borrowings, see Kevin W. Fogg, 'Indonesian Islamic Socialism and its South Asian Roots', Modern Asian Studies, 53, 6 (2019), pp. I736-176r.

${ }^{6}$ For a full bibliography of Tan Malaka's writings, see Harry Poeze, Verguisd en vergeten. Tan Malaka, de linkse beweging en de Indonesische revolutie, 1945-1949 (Leiden: Koninklijk Instituut voor Taal-, Land- en Volkenkunde, 2007), pp. 2007-2036.
} 
Indonesians to popularize Marx's ideas by writing about them in Malay, a fact which gave him a reputation as a formidable political intellect but equally earned him the enduring suspicion of the colonial authorities, who had him banished from the country in 1922.

The period from I9I4 to I927 was not only a time of Marxist propagandizing, it also saw the initial wave of communist political mobilization in Indonesia, climaxing in the abortive anti-colonial revolution launched by the PKI in Java and Sumatra in $1926-27 .^{7}$ The failure of this rebellion, which was followed by the mass arrest, deportation, and execution of political radicals, marked the end of an era. Malay-language communist newspapers were suppressed. Tan Malaka ceased to publish after 1926, going into hiding in China and Singapore. Communist politics in Indonesia did not reach the same level of intensity until the close of the Second World War, with the PKI retaining only a shadowy existence as an underground organization. ${ }^{8}$ The process of translating Marx's ideas into Malay is entwined with this political narrative. It ran in parallel to, and was intended to accelerate, a gathering insurrection against the colonial government. Translating Marxism was part of a wider effort to politicize the Indonesian people, to encourage new ways of thinking and talking about politics, which the communists believed could inspire change and hasten Indonesia's social and political development.

\section{Assessments of Indonesian Marxism}

In his overview of the importation of foreign political terms in Indonesia, Benedict Anderson commented on the ease with which Indonesians adapted a Marxist political vocabulary to Malay. What they did, for the most part, was transliterate rather than translate Marx's categories. In his view, Indonesians saw Marxism as a universal system which was as relevant to their own circumstances as it was to the West and so could be transliterated into Malay without great modification: 'Dutch terms were naturalized by committedly anticolonial activists: revolutie ... repolusi; partij ... partai; actie ... aksi; socialistisch ... sosialis. But the fundamental

\footnotetext{
${ }^{7}$ See Harry J. Benda and Ruth T. McVey, The Communist Uprisings of $1926-1927$ in Indonesia: Key Documents (Ithaca: Cornell University Press, I96o).

${ }^{8}$ On the underground Indonesian Communist Party, see Anton Lucas (ed.), Local Opposition and Underground Resistance to the Fapanese in Java 1942-1945, Monash Papers on Southeast Asia No. I3 (Melbourne: Aristoc Press, 1983).
} 
assumption was that these were all terms for universals. ${ }^{99}$ These universals, Anderson claimed, appealed to an increasingly cosmopolitan, educated elite in Indonesia, who were being drawn into world affairs through their reading of newspapers. Their use of transliterated Marxist terms marked them out as members of a global republic of letters.

In what follows, I will argue that Anderson's thesis is only correct in part. Indonesian communists did indeed present Marxism as a universal system of foreign origin that exceeded the bounds of existing Indonesian idioms. Through the transliteration of Marxist terms such as proletarian (proletar), capitalism (kapitalisme), and communism (kommunisme) - none of which is considered in Anderson's study-Indonesian communists invited their readers to imagine themselves as part of the larger, global groups and processes that Marxist terminology evoked. It was because Marxism was not considered to be essentially local that it could be used to modernize Indonesian political thinking (a task which many Indonesian intellectuals believed was essential in the early twentieth century) by introducing the universal and 'scientific' concepts of Marxist political thought. As Ruth McVey has argued, 'communism represented an efficacious teaching - an ilmu, a science which would enable people to overcome their colonial condition'. ${ }^{10} \mathrm{McVey}$ did not develop this claim but, as we shall see, members of the PKI did believe that Marxism was a universal science (ilmoe in Malay, wetenschap in Dutch), superior to older Indonesian and Islamic prophetic forms of political forecasting, which could be used to effectively resist Dutch rule.

In their evaluations of Indonesian Marxism, both McVey and Anderson imply a strong contrast between Marxism, which they see as modern and universal, and Indonesian political idioms, which they define as limited and traditional. As McVey has put it, 'the development of the Indonesian Communist movement reflects in the first place the crisis of confrontation between modern and traditional worlds which Indonesia has been undergoing in the past century'. ${ }^{11}$ Anderson linked the arrival of Marxist terms with the coming of other modernities in colonial Indonesia: the railway and the newspaper, which in his view upended

\footnotetext{
${ }^{9}$ Benedict R. O’G. Anderson, 'Language, Fantasy, Revolution: Java I9oo-1950', in Making Indonesia, Daniel S. Lev and Ruth McVey (eds) (Ithaca: Cornell University Press, I996), pp. $26-40$, at p. 35 .

${ }^{10}$ Ruth McVey, 'Teaching Modernity: The PKI as an Educational Institution', Indonesia, 50 (Oct. I990), pp. 5-27, at p. 6.

${ }^{11}$ Ruth T. McVey, The Social Roots of Indonesian Communism (Brussels: Centre d'e'tude du SudEst asiatique et de l'Extrême-Orient, I970), p. 2.
} 
existing ways of seeing the world and helped to foster a new global imagination among Indonesians. ${ }^{12}$ On this account, the PKI emerges as the bearer of Western modernity, embodied above all in its use of Marxist terms. It was in this vein that Herbert Feith and Lance Castles judged that Indonesian 'Communists went further than any other major party in breaking with the past and taking their concepts directly or indirectly from the West'. ${ }^{13}$

I will argue that, in contrast, Indonesian Marxism, though global in its outlook, was also closely entwined with vernacular discourses in the igios and I920s, and that its 'universal' concepts were drawn from Malay and Islamic sources as well as from the West. This blending of discourses is best appreciated by looking at the language used by Indonesian communists in their translation of Marx's ideas. Even those committed to 'scientific' Marxism drew extensively on local and Islamic vocabularies, with deep roots in Indonesian history, as they explained Marx's categories. This line of argument follows Christopher Bayly's suggestion, made in his outline of a 'global intellectual history', that historians should be sensitive to how, as they spread, foreign ideas interact with existing patterns of religion and culture. ${ }^{14}$ Examining how foreign concepts are translated, transliterated, and left untranslated provides a clear means of doing this. ${ }^{15}$ As Samuel Moyn and Andrew Sartori have argued 'conceptual mediation, always takes place in linguistically embodied media', which entails 'the contact of two particular languages, each with their own historical trajectories, semiotic ecologies, and hence specific possibilities of mutual translatability'. ${ }^{16}$ Such an approach is especially apposite with regard to Marxism, where it is tempting to assume that Marx's concepts were static across borders, since the concepts themselves claimed universal applicability. ${ }^{17}$ Even if

${ }^{12}$ Anderson, 'Language, Fantasy, Revolution', p. 28.

${ }^{13}$ Herbert Feith and Lance Castles, Indonesian Political Thinking 1945-1965 (Ithaca: Cornell University Press, I970), p. I5.

${ }^{14}$ C. A. Bayly, 'History and World History', in A Concise Companion to History, Ulinka Rublack (ed.) (Oxford: Oxford University Press, 20i I), pp. 3-26, at p. 20.

${ }^{15}$ See, for example, Michael Lackner (ed.), New Terms for New Ideas: Western Change in Late Imperial China (Leiden: Brill, 200I).

${ }^{16}$ Samuel Moyn and Andrew Sartori, 'Approaches to Global Intellectual History', in Global Intellectual History, Samuel Moyn and Andrew Sartori (eds) (New York: Columbia University Press, 2013), pp. $3-32$, at p. Iо.

${ }^{17}$ Hélène Carrère d'Encausse and Stuart Schram have argued that this was the assumption of many Western Marxists, who were more concerned to apply what they saw as universal Marxist categories to foreign countries than to understand how these 
terms such as 'proletariat' and 'capitalism' appeared universal, being derived, in theory, from observation of empirical facts and material relationships, in practice they were embedded in vernacular discourses or exchanged for vernacular terms in ways that altered their meanings. Arif Dirlik has observed this with regard to Mao's writings, also begun in the interwar years, which, in his view, placed 'Marxism within a Chinese world of discourse that in its vocabulary is not readily accessible to the outsider, no matter how thoroughly s/he may be armed with Marxist concepts'. ${ }^{18}$ The same is true for Indonesian interpreters of Marx. It is the way they translated Marx's concepts that reveals how Indonesian discourses interacted with Western Marxism.

The entanglement of Indonesian Marxism with other ideologies has been noted by historians. Both McVey and Shiraishi have commented on the doctrinal heterogeneity of Indonesian communism in the IgIos and I920s, drawing attention to the prominence of Islam and nationalism in the rhetoric of the PKI. ${ }^{19}$ To some observers, the resulting synthesis was something of a mess. In Ig68 the Swedish economist Gunnar Myrdal complained that Indonesian socialism was poorly theorized, being 'expressed in very vague and confused terms', which he put down to 'the relative scarcity of intellectuals capable of articulating and developing socialist ideology, and ... efforts made to incorporate religious beliefs' ${ }^{20}$ Translation, however, is frequently a difficult and tangled business. Indeed, as the philosopher Raymond Geuss has commented, political writing in general is often characterized by imprecision and rarely conforms to rigorous standards of coherence. $^{21}$ The blending of religious and Marxist terms, which appeared confusing and chaotic to Myrdal, was part of the process of making Marxism comprehensible and appealing to an Indonesian audience comprised overwhelmingly of Muslims, for whom Islamic terminology was more familiar than the language of Marx and Engels.

categories were adapted in different contexts. See Hélène Carrère d'Encausse and Stuart R. Schram, Marxism and Asia (London: Allen Lane, I969), p. viii.

${ }^{18}$ Arif Dirlik, 'Mao Zedong and "Chinese Marxism"', in Marxism Beyond Marxism, Saree Makdisi, Cesare Casarino and Rebecca F. Karl (eds) (London: Routledge, I996), pp. II9I48, at p. I20.

${ }^{19} \mathrm{McVey}$, The Social Roots of Indonesian Communism, pp. 5-6; Shiraishi, Age in Motion, pp. xi-xvi.

${ }^{20}$ Gunnar Myrdal, Asian Drama: An Inquiry into the Poverty of Nations (Harmondsworth: Penguin Books, i968), Vol. I, p. 373 .

${ }^{21}$ Raymond Geuss, Philosophy and Real Politics (Princeton: Princeton University Press, 2008), p. 2. 
In the terms of Oliver Wolters, Indonesian translators of Marx were engaged in a process of 'localization', that is, an attempt to translate foreign Marxist materials so as to bring them closer to local cultural norms. ${ }^{22}$

Feudalism, for example, was translated as keradjaan (the rule of the raja) and linked with the dominance of the ningrat (a Javanese term for aristocracy), while the proletariat was equated with the Kromo (a Javanese term for the common people). Arabic terms associated with Islam, such as nafsoe (lust) and djahat (evil), were woven into communist writings to add a moral dimension to the Marxist critique of capitalism that would resonate with Indonesian Muslims. The style of Indonesian Marxism that emerged was multilingual, with a push and pull between international and local political registers, between transliteration and translation. Not only were universal terms imported from the West, some local political categories, such as radja and ningrat, were raised to a universal status by being elided with Marxist categories, while others, such as Kromo, were used to ground Marxism more firmly in the Indonesian archipelago. That Marxism was expressed in both vernacular and foreign terms reflects the position of the translators of Marx's ideas, who had a foot in both linguistic worlds, being literate in both Dutch and Malay. They sought to make Marxism intelligible in Malay, which entailed the use of indigenous and Islamic concepts, while keeping Marx's original vocabulary, which denoted their own high intellectual and cosmopolitan status, and was thought to be essential to the universality of Marxism itself.

\section{Politics in a multilingual society}

The Dutch East Indies, despite its name, was a multilingual society. Dutch was one language among many used across the vast Indonesian archipelago. On the island of Java alone, three main indigenous languages were spoken: Javanese, Madurese, and Sundanese. The lingua franca which connected these diverse tongues was Malay. It was used by Europeans to communicate with 'natives' and by speakers of different indigenous languages to converse with one another. ${ }^{23}$

${ }^{22}$ O. W. Wolters, History, Culture, and Region in Southeast Asian Perspectives (Ithaca: Cornell University Press, I999), pp. 56-57. Wolters preferred localization to the term syncretism because it conveyed 'the initiative of the local elements responsible for the process and the end product' and called 'attention to something else outside the foreign materials'.

${ }^{23}$ H. M. J. Maier, 'From Heteroglossia to Polyglossia: The Creation of Malay and Dutch in the Indies', Indonesia, 56 (Oct. I993), pp. 37-66, at p. 47. 
Indonesians who were literate in both Dutch and vernacular languages were central to the functioning of the colonial system. They were needed to mediate between the indigenous majority and the European minority that dominated the upper ranks of the state bureaucracy and owned most of the large businesses. ${ }^{24}$ The colonial government's announcement of its intention to follow an 'Ethical Policy' (Ethische Politiek) from I90I, which was aimed at improving the welfare of the general population, increased the demand for Dutch-speaking Indonesians still further. To carry out its policy of 'development' (ontwikkeling), the colonial state needed subjects capable of speaking and writing Dutch to act as conduits for 'advanced' Western practices in medicine, agriculture, engineering, and administration. ${ }^{25}$ To this end, a number of European-style schools for natives were opened: in Igoo only I,500 natives attended European schools; by 1928 the figure was $6,500 .{ }^{26}$ The cumulative effect of this expansion was substantial. Although Indonesians with Western-style educations remained a tiny minority of the overall population, by 1930 there were I70,000 natives who were literate in Dutch, roughly the same number as Dutch-speaking Europeans. ${ }^{27}$

Anderson has argued that learning Dutch was often a highly disquieting process for Indonesians because it fundamentally estranged them from their original culture. As he puts it, 'the advance to bilingualism ... in itself created a profound mental and spiritual displacement'. ${ }^{28}$ One response to this displacement was for Indonesians to attempt to assimilate entirely to Dutch culture, that is, for Western-educated Indonesians to turn their backs on the 'traditional modes of thinking' which they now perceived as being discredited. ${ }^{29}$ This route was difficult, however, because the racial hierarchies ingrained within colonial society meant that Indonesians were never fully accepted into

${ }^{24}$ In 1925 , Europeans owned 54 per cent of enterprises employing more than six people; in 1938,92 per cent of the higher positions in the civil service were occupied by Europeans. See George McTurnan Kahin, Nationalism and Revolution in Indonesia (Ithaca: Cornell University Press, 1952), pp. 29, 35 .

${ }^{25}$ For a study of the Ethical Policy, see Suzanne Moon, Technology and Ethical Idealism: A History of Development in the Netherlands East Indies (Leiden: Leiden University Press, 2007).

${ }^{26}$ Adrian Vickers, A History of Modern Indonesia (Cambridge: Cambridge University Press, 2005), p. 4I.

${ }^{27}$ Maier, 'From Heteroglossia to Polyglossia', p. 37.

${ }^{28}$ Benedict R. O'G. Anderson, Language and Power: Exploring Political Cultures in Indonesia (Ithaca: Cornell University Press, 1990), p. I25.

${ }^{29}$ Ibid. 
European circles. The Javanese noble Suwardi Suryaningrat, who graduated from the college for native doctors, at the time the most advanced educational institution open to Indonesians, wrote a polemical tract in I9I3 titled Als ik eens Nederlander was ('If I were a Dutchman'), drawing attention to the hypocrisy of the Dutch who celebrated their own freedoms while denying these rights to Indonesians. In his view, while Indonesians were encouraged to imitate Dutch mores, they were nonetheless denied parity with Europeans on account of their race. ${ }^{30}$

Another response to Western-style schooling, which in Anderson's view was more fruitful, was for Indonesians to use their Dutch educations to attempt to build connections between European ideas and their own culture. This search for connections entailed the creation of a new style of speaking - a 'counterlanguage to Dutch, a modern, nationalistic language, which would in itself reestablish the connection with Indonesian traditions'. ${ }^{31}$ The primary vehicle of this language was Malay, though a form of Malay inflected with Dutch terms and Western concepts, through which Dutch-educated Indonesians could communicate with their less educated fellow countrymen and women. Rudolf Mrázek has drawn attention to the cultural pluralism of European-educated Indonesians, describing them as 'a colorful, and often dazzling, fast-moving crowd that enjoyed being seen as connoisseurs of Greek philosophy and the French Revolution as much as of wayang, the Javanese shadow puppet theatre (if they happened to be Javanese), or, and this very much so, of Hollywood'. ${ }^{32}$ This cohort, who studied in Western-style schools in the IgIos and reached adulthood around the time of the Bolshevik Revolution, were the first Indonesians to embrace Marxism and attempt to translate Marx's ideas.

The translation of Marxism into Malay was part of the effort by Western-educated Indonesians to express European ideas in a vernacular idiom and so reconnect with their original culture. Indonesian Marxists were almost exclusively products of Western-style schools. Tan Malaka, for example, graduated in I9I3 from the Kweekschool (teacher training college) in Fort De Kock (Bukittinggi), West Sumatra, before continuing his studies in the Netherlands, where

\footnotetext{
${ }^{30}$ On the controversy caused by Suwardi's pamphlet, see Kees van Dijk, The Netherlands Indies and the Great War, I9I4-I9I8 (Leiden: Brill, 2007), pp. 57-6I.

${ }^{31}$ Anderson, Language and Power, pp. 125-126.

${ }^{32}$ Rudolf Mrázek, Engineers of Happy Land: Technology and Nationalism in a Colony (Princeton: Princeton University Press, 2002), p. I48.
} 
he encountered Marx's works in Dutch translation in I917. ${ }^{33}$ The writings of Indonesian communists, however, were primarily directed not at the relatively small pool of Dutch speakers but at the much larger constituency of Indonesians literate in Malay. As Anderson has commented, while Dutch was the 'vehicle of comprehension' of Marxism, Malay was the 'vehicle of attack' that spread Marxist ideas to the broader Indonesian public. ${ }^{34}$ Writing about Marxism in Malay was a deliberately subversive act, since it spread Western ideas beyond the handful of 'natives' that the colonial state permitted to study Dutch. Indonesians educated by the government, who were intended to smooth the functioning of colonialism, ended up using their mastery of Western languages to translate and popularize ideas that challenged both local systems of thought and the logic of colonialism itself.

\section{The reception of Marxism in colonial Indonesia}

The first explicitly socialist organization begun in the Indonesian archipelago was the Indische Sociaal-Democratische Vereeniging (Indies Social-Democratic Association, ISDV), which was founded in Surabaya in I9I4. The ISDV initially had 60 members, almost all of whom were Dutch, many also being members of the Sociaal-Democratische Arbeiderspartij (Social-Democratic Workers' Party, SDAP), the leading left-wing party of the Netherlands. The first chairman of the ISDV was Henk Sneevliet, a Dutch railway worker and trade unionist, who had moved to the Indies in I9I3 and was active in the Vereniging van Spoor-en Tramwegpersoneel (VSTP), the Indies union of train and tram workers. ${ }^{35}$ The ISDV operated in the relatively liberal political climate created by the Ethical Policy, following the easing of restrictions on the press in 1906. In October I9I5 Sneevliet and his deputy, Asser Baars, began a party journal, Het Vrije Woord ('The Free Word'), written entirely in Dutch, which carried articles on international affairs and socialist political thought.

Sneevliet, despite being unable to speak Malay or any local language, was keen to reach out beyond the confines of the Dutch community to

${ }^{33}$ Tan Malaka, From Fail to Fail, Helen Jarvis (ed.) (Athens: Ohio University Press, I99i), Vol. I, p. 27.

${ }^{34}$ Anderson, Language and Power, p. 136.

${ }^{35}$ For a biography of Henk Sneevliet, see Tony Saich, The Origins of the First United Front in China: The Role of Sneevliet (Alias Maring) (Leiden: Brill, I99I). 
the larger Indonesian population. Through his connections in the railway industry he recruited Semaun, a Javanese train worker, to the ISDV. He also made an alliance with the Sarekat Islam (Islamic Association), a mass party for Indonesian Muslims founded in I9I2, which claimed a membership of over two million by r919. ${ }^{36}$ Sneevliet hoped to use the Sarekat Islam's mass support to spread socialist ideas across the archipelago and attract capable Indonesian members. This strategy was particularly successful in Semarang, where the ISDV dominated the local Sarekat Islam branch, through which Tan Malaka, then working as a schoolteacher, was recruited in I92I. A number of other Western-educated Indonesians were also drawn to the ISDV through the Sarekat Islam, including Musso and Alimin, both of whom were graduates of the Batavia teacher training college. Darsono, a Javanese aristocrat, became a committed communist after hearing Sneevliet defend himself against the charge of sedition in $1917 .{ }^{37}$

At the ISDV congress in 1920 it was decided that the ISDV should join the Communist International (Comintern) and so become a communist party, the first of its kind in Asia. It was also resolved that the new party should have a Malay name, Perserikatan Kommunist di India (PKI), to be used in conjunction with a Dutch name, Partij der Kommunisten Indie. Coining a Malay name reflected a broader shift in the party towards being more Indonesian in character and more closely entwined with the Sarekat Islam. The PKI's first chair, Semaun, was a leading figure within the Sarekat Islam, as was Tan Malaka, who succeeded him in 192I. The PKI sought to radicalize the Indonesian population by spreading propaganda through Sarekat Islam branches, trade unions, and schools. This strategy created a rift within the leadership of the Sarekat Islam, however, due to the concerns of some of its leaders over the communists' secular language of international class war and their association with the atheist Communist International. At its 1921 Congress, the central branch of the Sarekat Islam imposed party discipline and expelled all PKI members, triggering a major internal split within the organization which fractured into pro-communist (red) and anti-communist (white) branches. All hopes of a reconciliation between the central Sarekat Islam and the PKI were ended in 1923, when pro-PKI branches of the Sarekat Islam withdrew to form the Sarekat Rakyat (People's Association).

${ }^{36}$ Kahin, Nationalism and Revolution in Indonesia, p. 66.

${ }^{37}$ R. McVey, The Rise of Indonesian Communism (Ithaca: Cornell University Press), p. $3^{6 .}$ 
The PKI enabled Indonesians with Western-style educations, many of whom were drawn to the party through the Sarekat Islam, to access Marxist political writings in Dutch. In a 1922 report for the Comintern, Semaun stated that the party had at its Semarang base 'a number of books by well-known European Communists and Socialist writersMarx, Engels, Lenin, Trotsky, Gorter, Roland Holst, Radek, Kautsky, and many others. Books in Dutch are extremely important for our party. We by no means have a complete library, but what we do own is studied extremely carefully. ${ }^{38}$ Familiarity with the works of Marx and Engels was seen as an essential part of the training of a PKI cadre. ${ }^{39}$

Marxist ideas gleaned from these Dutch texts were spread to the Indonesian public through the Malay-language press organs of the PKI, the VSTP, and the 'red' branches of the Sarekat Islam. By the early I920s there were a number of Malay-language socialist newspapers circulating in the Indies: Soeara Rajat (The Voice of the People, started I9I9), the PKI's official paper; Sinar Hindia (The Light of the Indies, I918), the journal of the Semarang Sarekat Islam; and Si Tetap (The Steadfast One, I918), the paper of the VSTP. The VSTP press in Semarang also printed several socialist pamphlets, such as Semaun's Penoentoen Kaoem Boeroeh ('A Guide for the Workers', 1920) and Tan Malaka's Parlement atau Sorjet? ('Parliament or Soviet?', I92I). In I923, the VSTP press published the first Malay translation of Marx and Engels' Communist Manifesto, which had been serialized in Soera Ra'jat in April of that year. ${ }^{40}$ The PKI released an introductory Padoman (handbook) to communism in I923, again published in Semarang. ${ }^{41}$

Taken together, these books, pamphlets, and newspapers represent the first sustained engagement with Marxism in the Malay language. Their authors were mainly Indonesians educated in the colonial school system, like Tan Malaka, whose knowledge of Marxism came from their readings of Marxist texts in Dutch. Their Malay-language writings, however, were deliberately aimed at those unfamiliar with European languages and Western political thought. It was because these texts spread radical Marxist arguments to the Indonesian masses that they so

\footnotetext{
${ }^{38}$ Semaun, 'An Early Account of the Independence Movement', Indonesia, I (April I966), pp. $4^{6-75}$, at p. 75 .

${ }^{39}$ Semaun mentions both the Communist Manifesto and Das Kapital as important books on communism in Hikayat Kadiroen (1920). See Semaoen, The Story of Kadirun: A Novel, trans. Ian Campbell (Jakarta: Lontar, 2014).

${ }^{40} \mathrm{McVey}$, The Rise of Indonesian Communism, pp. 433-434.

${ }^{41}$ Padoman Perserikatan Kommunist India (Semarang: n.p., n.d. [I923]).
} 
alarmed the colonial government. In I92I, Tan Malaka was arrested and questioned by police over sections of Parlement atau Sorjet? which they judged to be treasonous. ${ }^{42}$ The next year he was banished from the country. In what follows, I will examine how these texts used and explained Marxist concepts, focusing specifically on how key epistemological, political, and ethical concepts, such as science, capitalism, feudalism, greed, and the righteousness of revolution were variously translated and transliterated by Indonesian communists, and what the implications of their interpretive strategies were.

\section{The science of communism}

The first task of Indonesian communists was to explain the nature of their doctrine to the public. What was kommunisme, a word evidently of foreign origin? In an article for Sinar Hindia, published in I92I, Darsono narrated the origins of communism. Rejecting the charge of Fachruddin, an anti-communist affiliated to the Sarekat Islam who had alleged that communism was the invention of Mikhail Bakunin, Darsono replied, 'It is not Bakunin who is the author of this science [ilmoe]; this science is already several thousand years old.' Citing H. P. G. Quack's three-volume history of socialism, De Socialisten. Personen en stelsels (I875-97), he pointed to Plato and Jesus as early exponents of communism but gave pride of place to Marx and Engels as the true teachers (goeroe) of modern, revolutionary communists. ${ }^{43}$ The PKI's Padoman claimed that Marx and Engels had not only outlined a revolutionary vision of communism, they had also made communism scientific: it was 'KARL MARX and FRIEDRICH ENGELS', the 'great teachers [goeroe]' of communism, who first 'put Communism on a scientific basis (set it on a foundation of wetenschap)', laying the intellectual groundwork for a global transition to communist society which had begun with the I9I7 Bolshevik revolution in Russia. ${ }^{44}$

In what sense, though, was communism a science? A I92I article from Sinar Hindia, titled 'Kommunisme tingkat pertama' ('The First Level of Communism'), explained that communism revealed the laws that

${ }^{42}$ Tan Malaka, Toendoek kepada kekoeasaan tetapi tidak kepada kebenaran (Berlin: n.p, n.d. [I922]), p. 4 .

43 'Kommunisma dan Islamisma', Sinar Hindia, I4 February I92 I.

${ }^{44}$ Padoman Perserikatan Kommunist India, p. $5 \mathrm{I}$. 
governed social development. The author, Soekin, claimed that Marx had discovered 'the laws [wet] of motion of the progress of society'. ${ }^{45}$ Tan Malaka fleshed out this notion in Semangat Moeda (1926), explaining that societies were not static but progressed through a series of stages, from the feudal age (djaman feodalisme) to the capitalist age (djaman kapitalisme), to the era of communism (djaman Kommoenisme), which would finally resolve the class struggle. ${ }^{46}$

The choice of wet to describe Marx's law of historical development, rather than the Malay word undang-undang, or the Arabic-derived hukum, and the description of Marxism as a wetenschap linked Marxism with Dutch and so with the West, allowing Indonesian communists to align themselves with Western science rather than Indonesian systems of thought. Indeed, the notion of history as a series of progressive stages diverged markedly from conventional Javanese styles of describing the past, which tended to see history as cyclical. Anderson, drawing on the work of Sartono Kartodirdjo, has claimed that the 'traditional Javanese view of history' was to see the past as 'series of recurrent cycles'. Anderson has noted the specific 'contrast drawn between the djaman mas (golden age) and the djaman edan (mad age). These two types of historical epochs were typically seen as times of order and times of disorder', which generally meant periods of rising or declining ruling dynasties. ${ }^{47}$ Marx's vision of history was very different. The djaman feodalisme (feudal age) and djaman kapitalisme (capitalist age) were defined not by reference to dynastic politics but by their prevailing labour relations and technologies. They were, moreover, not oscillations on a repeating theme but stops on the way to the telos of the djaman Kommoenisme, the end-point of history.

Marxism was not entirely divorced from Indonesian idioms of history, however, in that it retained a millenarian overtone, not least in its language of the approaching era of communist egalitarianism, which resembled the djaman mas (golden age) of Javanese historiography. Communist publications stressed that Marx's theory of history showed that revolutions were inescapable in societies polarized between a ruling propertied elite and the workers, meaning that history was a series of confrontations between oppressor and oppressed, resulting eventually in

\footnotetext{
45 'Kommunisme tingkat pertama', Sinar Hindia, 24 September I92I.

${ }^{46}$ These transliterated terms are used throughout by Tan Malaka, Semangat Moeda (De fonge Geest) (Tokyo: n.p., I926).

${ }^{47}$ Benedict Anderson, 'The Idea of Power in Javanese Culture', in Culture and Politics in Indonesia, Claire Holt (ed.) (Ithaca: Cornell University Press, I972), pp. I-70, at pp. 20-2I.
} 
the creation of a just society. The PKI's communist handbook summarized this view: 'There was once a time when countries were based on the work of slaves [boedak], then there arose the power of the nobility [bangsawan], with their serfs [hamba], that is a period that is known as feudalism and since the end of the i8th century the present system that is called capitalism, and after the death of capitalism comes Communism. ${ }^{48}$ The use of Indonesian social terminology here-boedak for slave, bangsawan for nobility - rather than terms from Dutch, such as lijfeigene (serf) or baron, emphasized the fact that Marx's historical narrative applied equally to Indonesia. Indeed, Marx's vision of historical change could be elided with eschatological narratives indigenous to Indonesia. This elision was spelled out in a I924 article in Sinar Hindia, written under the pen name KROMO (common person), which claimed that communism, as a doctrine 'based on wetenschap', offered the only genuine means of creating a society like that of the 'Ratoe Adil', the 'just king' prophesized in Javanese folklore, whose reign would be one of peace and fairness, a vision which remained popular in early twentieth-century Java. ${ }^{49}$

Despite their millenarian language, Indonesian communists believed that their doctrine was more scientific than earlier prophecies of an imminent golden age because of their thorough knowledge of historical trends. In Semangat Moeda, Tan Malaka wrote that in the feudal age, the schemes for bringing about a new government involved soothsayers and incense. A goeroe or a Kijahi [Islamic religious expert] would divine from books or palm reading when the Ratoe Adil or Imam Mahdi would come. ${ }^{50}$ The success of communism was not guaranteed by divine prophecy, like the coming of the Ratoe Adil or Imam Mahdi, whose arrival signalled the end of the world in Islamic eschatology, but by the logic of historical materialism. The communists believed that Marx had proven that communist society would inevitably emerge from capitalism as a result of the historical development of capitalism itself. This prediction, they claimed, was based on an empirical survey of history which revealed a consistent pattern in politics. As such, communist political reasoning represented a major departure in Indonesian

${ }^{48}$ Padoman Perserikatan Kommunist India, p. 46.

49 'Ratoe Adil atau Imam Mahdi', Sinar Hindia, 2i May i924. The Sarekat Islam leader Tjokroaminoto was compared to the 'Ratu Adil', as was Sukarno. See Shiraishi, Age in Motion, pp. 66-67; and Rudolf Mrázek, Sjahrir: Politics and Exile in Indonesia (Ithaca: Cornell University Press, I994), pp. 87-88.

${ }^{50}$ Tan Malaka, Semangat Moeda, pp. I3-I4. 
political thought. Marxists like Tan Malaka claimed knowledge of those interventions that would be effective not because they had religious inspiration but because they understood through empirical observation how societies evolved and when they were ripe for revolutionary change.

The communists presented this as a victory for science (ilmoe or wetenschap) over mystical and spiritual thinking (kebatinan), which was associated primarily with Java's religion. Semaun judged that Indonesians, like other peoples from warmer climates, had been historically inclined towards mysticism:

People in a warm country are quicker to accept supernatural beliefs [ilmu gaib] like 'religion' [agama] and 'spiritual' [batin] salvation. Because they are influenced by the hot climate, their wishes and thoughts frequently turn tacitly toward the mystical [kebatinan]. This is the reason why warm countries like those of the Arabs, Hindus, Chinese etc. are important sites in the development of supernatural beliefs, or are often said by Lord Allah the All-Powerful to be the place of origin of great Prophets and Sages. ${ }^{51}$

In Semaun's view, the colonization of Indonesia was due to this Indonesian lack of worldliness: 'Indonesia must be ruled by the Dutch for the time being, while it lacks intelligence and wisdom in matters of science [ilmu] and material knowledge [pengetahuan lahir]. ${ }^{52}$ Tan Malaka directly spelled out communism's opposition to mysticism. In Semangat Moeda he wrote 'Communism is not spiritual knowledge [ilmoe batin], that comes after burning a picul of incense. It is a social system, contained within present society. ${ }^{, 53}$ Communism was derived from empirical observation, not revelation:

We Communists do not get this image of Communism from the passions of dreamers or astrologers. We are not commanded by Karl Marx to memorize the nature of Communism and keep praying for Heaven to come to Earth. Instead we have a clear explanation from Marx, that the progress of Feudalism gave rise to Capitalism, and the present progress of Capitalism is bringing about Communism. Just as the nobles [kaoem bangsawan] were overthrown by the capitalists [Kaoem Hartawan], so the capitalists will be defeated by the workers. This defeat does not arise from mystical [mistik] or magical [gaib] causes but for tangible reasons, that can be seen and perceived. ${ }^{54}$

\footnotetext{
${ }^{51}$ Semaoen, Penuntun Kaum Buruh (Yogyakarta: Penerbit Jendela, 200o), pp. 8-9.

${ }^{52}$ Ibid., p. II.

${ }^{53}$ Tan Malaka, Semangat Moeda, p. I3.

${ }^{54}$ Ibid., pp. IO-II.
} 
For the partisans of the PKI, communism was a new, scientific style of politics. As such, in their view it represented a decisive improvement on older Indonesian forms of political analysis. The communists phrased this contrast in language familiar to their audience, using the conventional contrast of lahir (the external world) and batin (the internal world). ${ }^{55}$ Communism was based on the observation of lahir, distinguishing it from mystical thinking, which was intuited from batin. Communists characterized previous generations of Indonesians as being preoccupied with batin, whereas they prioritized the external arrangements of the world-lahir - in their pursuit of a better society. While mysticism was depicted in the vernacular as kebatinan, agama, or gaib, the communists drew on Dutch to describe their doctrine as wetenschap. This suggested that while Dutch had an insufficiently rich vocabulary to describe Indonesian religion, it was a suitable medium for expressing the scientific nature of communism, reflecting the view that spiritual thinking was Indonesian, or perhaps Asian, in nature, while science was more closely associated with the West.

Tan Malaka argued that Indonesians were becoming less mystically inclined as the advance of capitalism integrated the country into the world economy. In Massa Actie he wrote: 'Where capitalism arises, and lays down roots, there a healthy mind and rationalism begins to grow, and superstitious beliefs begin gradually to disappear. So, the psychology and ideology and reason of the Indonesian people moves in step with the fickle cunning of capitalism.' Indonesian examples abounded: 'Look only at the difference in the progress of thought between the Javanese and our brothers in Halmahera, or between our comrades in Surabaya and Semarang, who are [politically] conscious, and the people of the unindustrialized villages. ${ }^{56}$

In attacking mysticism as an Indonesian peculiarity that would be weeded out through the introduction of superior foreign ideas, the communists were taking sides in a more general debate then occurring in Indonesian society. Efforts to reform Indonesian religion had been gathering pace since the turn of the twentieth century. Indonesians educated in Egypt and Mecca brought back the doctrines of Islamic modernism, articulated most fully by Jamal al-Din al-Afghani and Muhammad 'Abduh in the late nineteenth century. These reformers sought to eliminate mystical practices among Muslims, which they

\footnotetext{
${ }^{55}$ Clifford Geertz, The Religion of Java (Chicago: Chicago University Press, I96o), p. 232.

${ }^{56}$ Tan Malaka, Aksi Massa (Yogyakarta: Penerbit Nararsi, 2013), p. 96.
} 
considered un-Islamic accretions, and advocated a return to what they judged to be the purer, original textual sources of Islam. Modernists, like the communists, placed a high value on Western science, which they believed should be emulated by Muslims. ${ }^{57}$ Modernist ideas were influential within the Sarekat Islam. Haji Agus Salim, who was briefly a member of the ISDV and became the deputy leader of the Sarekat Islam from 1915, was an exponent of modernism. ${ }^{58}$ Communists like Tan Malaka and Semaun, who were involved in both the Sarekat Islam and the PKI, were exposed to modernist ideas and are likely to have been familiar with the modernist critique of Indonesian mysticism. Their praise of wetenschap and denigration of local religious customs echoed the modernist demands to embrace Western science and abandon mysticism, revealing a considerable overlap between the communists and the Sarekat Islam regarding 'traditional' Indonesian Islam.

The communists' attachment to 'scientific' Marxism was not only a sign of the influence of Islamic modernism, it was also intended to distinguish them from the rebels of previous eras, who had drawn on what they saw as cruder indigenous and Islamic ideas of prophecy to guide their actions. As Sartono Kartodirdjo has documented, during the nineteenth century several peasant revolts against colonial rule were led by religious experts who 'developed and transmitted the time honoured prophecies or vision of history concerning the coming of the Ratu Adil - the righteous king, ${ }^{59}$ It was this religiously inspired prophetic approach to political analysis that the communists rejected, presenting themselves as the bearers of a universal science of political analysis. Nonetheless, they did not abandon indigenous ideas or terms entirely. They grounded Marxism in a language familiar to their audience: communism was a wetenschap based on empirical observation, but it could also be described as an ilmoe, derived from lahir (the external world), formulated by the goeroe Marx, which would bring about a millenarian transformation of society. ${ }^{60}$ Marxism was distant enough from local idioms to be usefully

${ }^{57}$ Deliar Noer, The Modernist Muslim Movement in Indonesia 1900-1942 (Oxford: Oxford University Press, I973), pp. 302-306.

${ }^{58}$ Ibid., p. I 10.

${ }^{59}$ Sartono Kartodirdjo, The Peasants' Revolt of Banten in I888: Its Conditions, Course and Sequel ('s-Gravenhage: Martinus Nijhoff, ig66), p. 4.

${ }^{60}$ For a similar localization of Marx, see Har Dayal, Karl Marx: A Modern Rishi (Madras: Tagore and Co., n.d.). 
new and so reform what the communists characterized as superstition, but not so distant as to be incomprehensible to Malay-speaking Indonesians.

\section{Feudalism and capitalism in Indonesia}

Marxist texts furnished Indonesian communists not only with a theory of history and social change, but also with a typology of classes. Feudalism and capitalism, as well as being historical eras, were varieties of society. Marx argued that societies tended to be defined by the conflict between a ruling class and an oppressed class of workers. The famous opening of The Communist Manifesto declares: 'The history of all hitherto societies is the history of class struggles. Freeman and slave, patrician and plebeian, lord and serf, guild-master and journeyman, in a word, oppressor and oppressed stood in constant opposition to one another. ${ }^{61}$ These social groups, however, were drawn mainly from Marx's reading of European history: slavery was the defining institution of ancient Greece and Rome; feudalism described the society of medieval Europe. Capitalism, which was the major subject of both Capital and The Communist Manifesto, was judged by Marx to have emerged in Europe during the Middle Ages and early modern period.

If Marx's reference point for his analysis of class was European history, how easily could his classification of historical eras and social classes be applied to Indonesia? In Parlement atau Sorjet?, Tan Malaka claimed that Balinese and pre-Islamic Javanese society had historically been divided into castes (kasta) derived from Hinduism: 'the Brahma (priests [Pendita]), Ksatria (nobles [Bangsawan]), Wasia (the wealthy [hartawan] and the craftsmen [toekang]) and soedra (slaves [Boedak]), ${ }^{62}$ This caste system had a strict hierarchy, with the king (radja) at the top, and the Kromo (common people) having to be 'diligent, respectful, patient, and thankful' to their superiors, while wealth and power were reserved for

${ }^{61}$ Karl Marx and Friedrich Engels, Manifesto of the Communist Party, in Collected Works of Karl Marx and Frederick Engels (New York: International Publishers, 1976), Vol. 6, pp. 477519 , at p. 482 .

${ }^{62}$ Tan Malaka, Parlement atau Sorjet? (Semarang: Hoofdbestuur P. K. I., I92I), p. 70. The choice of 'boedak' here is polemical, since Sudra is often translated as 'commoner' (rendah) rather than 'slave'. Java, in fact, did not have a social order which strictly corresponded to Hindu castes, though social ranks were influenced by Indian castes. See Sartono Kartodirdjo, 'Bureaucracy and Aristocracy. The Indonesian Experience in the XIXth Century', Archipel, 7 (1974), pp. I5I-I68, at p. I52. 
the 'aristocracy [Ningrat] and clergy [pendeta]'. ${ }^{63}$ Such a social set-up strongly resembled European feudalism, as described by Marx, to the point where Tan Malaka could speak of ancien regime France as a country ruled by its own radja and ningrat class. ${ }^{64}$

Indonesian communists thus did not see feudalism as an exclusively Western form of society that would be incomprehensible to Indonesians, but as a universal type. If the defining features of feudalism were a predominantly agrarian economy and the presence of a monarchy and nobility, then the term was equally applicable to Indonesia. ${ }^{65}$ Indeed, the notion of a feudal system of class oppression had continuing relevance in contemporary Indonesia, as the princely states of Yogyakarta and Surakarta, in Central Java, were governed by monarchs under Dutch sovereignty, while the aristocratic ningrat elite retained a dominant position in the upper ranks of the indigenous civil service. Marx's terms thus existed alongside prevailing social classifications: in Parlement atau Sorjet?, Tan Malaka explained that feudalism (feodalisme) was 'the age of the Radja and the Radja-radja ketjil [royalty] ${ }^{66}$ Communist publications used djaman feodalisme (the feudal age) and djaman bangsawan (the age of the nobility) interchangeably. Serfdom may have been a European term, but there were a number of Malay words which the communists used to describe the coerced labourers of the past, such as boedak and hamba, both of which could be translated as 'slave' and which resonated with Java and Bali's own historic social hierarchies.

By equating feudalism with the rule of the radja and ningrat, Indonesian communists localized the language of Marx, associating it with the Hindu kingship and aristocracy familiar in the Indonesian archipelago. At the same time, they incorporated keradjaan into a universal stage of human history. For Tan Malaka, keradjaan was an adequate term to describe the governance of ancient China, the Islamic empire, India, and Europe before $1789 .{ }^{67}$ In this way the communists encouraged Indonesians to see their own past as being entwined with the histories of other nations. If the Majapahit empire (I292-circa I500), for example, was feudal, then

${ }^{63}$ Tan Malaka, Parlement atau Sorjet?, p. 7o.

${ }^{64}$ Ibid., p. 69 .

65 The same logic applied to the application of feudalism to Chinese history: see Albert Feuerwerker, 'China's Modern Economic History in Communist Chinese Historiography', The China Quarterly, 22 (June i965), pp. 3 ${ }^{\text {I-6I. }}$

${ }^{66}$ Tan Malaka, Parlement atau Sorjet?, p. 43.

${ }^{67}$ Ibid., p. 79 . 
it was one example of a generic type of society. As Anderson has put it, 'To be able to look at a high Javanese court official and reclassify him from "my lord" or perpatih (Grand Vizier) ... to orang feodal - a "feudalist" - situated him within an immense world-category. 68 This contrasted with the manner in which earlier generations of Indonesians had described their society. Rulers had once stressed the specificity and centrality of their polity. The kraton (palace) of a Javanese king was thought to be the centre of the world itself, not only the centre of their realm. The title Hamengkubuwono, held by the sultans of Yogyakarta since the eighteenth century, can be translated as 'Holder of the Cosmos'. ${ }^{69}$ The Minangkabau of West Sumatra, where Tan Malaka had spent his youth, conventionally divided the world into the Alam Minangkabau (the Minangkabau world) and the rantau (the world outside), implying a sharp distinction between their own region and the rest of the world, as well as a fundamental incommensurability between their society and all others. ${ }^{70}$ The communists sought to collapse this division, offering their readers a new classificatory scheme which placed Indonesia within a larger framework of world history, one that revealed the similarities between Indonesians and other peoples. This global feudal past was still comprehensible, however, in local terms, as an extension of keradjaan and ningrat. Marxism extended local categories as well as displacing them.

If feudalism could be seen as a universal stage of human history, what about capitalism? Capitalism was generally transliterated as kapitalisme, which suggested a foreign system with a theoretical quality. The PKI's communist handbook explained that capitalism had two defining features. First, production that was 'capitalistic' (kapitalistisch) was based on the pursuit of profit. Second, under capitalism one group owned all 'land, factories, mines, and other businesses', while 'the majority of mankind owns none of the means of production, that give rise to all the wealth of the world'. The owners of the means of production were called 'kaoem modal' (those with modal, meaning capital or assets) or 'kaoem kapital', while those who lived 'in dependency on the capitalist class (kaoem kapital)' were the 'kaoem proletar [proletariat]'. ${ }^{71}$ Tan Malaka

${ }^{68}$ Anderson, 'Language, Fantasy, Revolution', p. 35.

${ }^{69}$ Ibid., p. 27.

${ }^{70}$ See Taufik Abdullah, 'Modernization in the Minangkabau World: West Sumatra in the Early Decades of the Twentieth Century', in Culture and Power in Indonesia, Claire Holt, Benedict R. O’G. Anderson and James Siegel (eds) (Ithaca: Cornell University Press, I972), pp. $\mathrm{I}^{2} 9^{-245}$.

${ }^{71}$ Padoman Perserikatan Kommunist India, p. 2. 
added a third aspect to the definition of capitalism, emphasizing the connection between capitalism and industrialization. In Parlement atau Sorjet?, he wrote that capitalism entailed the 'employment of great machines. ${ }^{72}$ In Semangat Moeda, he described the flood of new technologies created in the capitalist era, such as trains, steam ships, and factories, which would have seemed fantastical by earlier standards. ${ }^{73}$

Capitalism was a useful explanatory term for the communists because it helped to describe the economic realities in early twentieth-century Indonesia. The notion of 'capitalistic' production well described Indonesian export industries, such as tea, sugar, and coffee, which were dominated by plantation owners who produced commodities to sell on a world marketplace for a profit. These industries had grown dramatically since the mid-nineteenth century. In I880, Indonesia produced 300,000 tonnes of sugar. By I931, the figure was three million tonnes, which constituted a fifth of the world's cane sugar supply. ${ }^{74}$ This growth of commodity capitalism was accompanied by an expansion of wage labour, making the notion of a society polarized between capitalists and proletarians seem apposite. On plantations in Java, Sumatra, and elsewhere, a small group of owners employed huge numbers of 'coolie' labourers. In Toendoek kepada kekoeasaan tetapi tidak kepada kebenaran ('Submission to Might, but not to Right', I922), Tan Malaka lamented that land encroachment by plantations had destroyed the old labour regime of Indonesia, reducing Indonesians to wage labourers: 'today there are no longer any craftsmen, captains or poets, but nearly all the boemiputera [native Indonesians] have become coolies and labourers' ${ }^{75}$ Technological change arising from the expansion of export capitalism was also visible across the Indonesian archipelago. Although Indonesian capitalism was primarily agricultural, the country nonetheless experienced industrialization, much of which was related to the processing of primary products. In Penoentoen Kaoem Boeroeh, Semaun noted that European investment had created 'sugar refineries, rice mills and so on' ${ }^{76}$

Marx's term kapitalisme was thus a productive one for Indonesians because it brought together under a single conceptual heading several

72 Tan Malaka, Parlement atau Soviet, p. 79.

73 Tan Malaka, Semangat Moeda, p. 4 .

${ }^{74}$ G. Roger Knight, Commodities and Colonialism, The Story of Big Sugar in Indonesia, I88o1942 (Leiden: Brill, 2013), p. I2.

${ }^{75}$ Tan Malaka, Toendoek kepada kekoeasaan, p. Io.

${ }^{76}$ Semaoen, Penuntun Kaum Buruh, p. I8. 
recognizable technological and economic changes in the country. The communists were not the first to describe these changes. The colonial government's Ethical Policy was, in fact, motivated in part by anxieties held by certain Dutch observers that the economic change experienced by Indonesians since the mid-nineteenth century had been traumatic and had not noticeably enriched the 'native' population. ${ }^{77}$ What was novel about the writings of Indonesian communists was that they sought to make their readers understand economic change in Indonesia as part of a larger global process - as the unfolding of world capitalism, which had been emerging since the eighteenth century. ${ }^{78}$ In Semangat Moeda, Tan Malaka claimed that seeing politics as a matter of class struggle within a global capitalist economy was the essential insight of the communists: 'Nationalists and Islamists in our country do not at all understand Marxism, specifically the existence and position of castes [kasta] in Indonesia and the relationship between caste and politics'. ${ }^{79}$

At a basic level, the communists claimed that capitalists were a recognizable group because they were rich. Tan Malaka translated capitalist as kaoem hartawan, meaning 'the wealthy' or 'those with property', the same translation that he gave for the Wesia caste of Bali. ${ }^{80}$ Yet the communists were asking their audience to see capitalists as a particular kind of wealthy person, as a kaoem modal or 'owners of capital'. ${ }^{81}$ The PKI's communist handbook explained that a capitalist was someone who owned 'modal', defined as 'MONEY AND OTHER GOODS THAT ARE USED TO GATHER PROFIT FROM THE LABOUR OF MEN FOR THE NEEDS OF ONE OR TWO MEN ONLY. So it is not only money that is called capital, but also land, mines, factories and other productive goods that are used to create profit, are all known as capital ... In Javanese, capital [modal] is called pawitan and in Dutch kapital. ${ }^{, 2}$ In a footnote, it was explained that capitalists were also known as the 'Bourgeoisie', which was 'a French word pronounced "boersoeasie", 83

As with feudalism, defining capitalists through a European idiom as kaoem kapital or 'bourgeoisie' allowed them to be more easily imagined

\footnotetext{
${ }^{77}$ See Moon, Ethical Idealism, p. I8.

${ }^{78}$ Tan Malaka, Parlement atau Sorjet.? p. 79.

79 Tan Malaka, Semangat Moeda, p. 3I.

${ }^{80}$ Ibid., p. I.

${ }^{81}$ Ibid., p. 9; Partondo, Manifest kommunist, p. I.

${ }^{82}$ Padoman Perserikatan Kommunist India, p. 22.

${ }^{83}$ Ibid.
} 
on a global scale. According to the PKI's Padoman, capitalists came from all nations; indeed, there was a variety of capitalists present in contemporary Indonesia:

In the Indies there is not only a Dutch capitalist class [kaoem kapital] that takes profit from the labour of the people of the Indies, but also a Japanese, English, German, Chinese, American and ... a capitalist class from the boemiputera themselves. So the capitalist class from these various nations not only exploits the people of the Indies, but also the working class from their own countries. This capitalist class is not just the enemy of the workers here in the Indies, they are the enemies of the workers in their own countries too. ${ }^{84}$

Unlike feudalism, however, it was less clear that capitalism was indigenous to Indonesia. There were local terms that could be translated as 'capital' (modal and pawitan), but no obvious word for a capitalist, that is, the owner of the means of production who employed labourers who did not own their own property, as opposed to the more familiar figure of the wealthy trader (saudagar). The PKI's Padoman drew heavily on Dutch terms to describe industrial capitalists as the "kaoem modal industrie' or 'industriekapitalist' ${ }^{85}$ Even commerce was considered by the communists to be somewhat foreign to Indonesians. Semaun characterized Indonesians as a 'patient and cultured' people, who 'did not join the other peoples in their race for greater riches'. This, he claimed, was why Indonesian traders had historically lagged behind Europeans and the Chinese in matters of commerce. ${ }^{86}$ In Massa Actie ('Mass Action', I926), Tan Malaka argued that while there had been some indigenous proto-capitalists in the time of the Majapahit empire, with 'batik, tile and ship companies with sizeable capital', it was nonetheless true that 'great nations' that had once existed in Java, Sumatra, and Borneo had never 'taken the step out of feudal society'. ${ }^{87}$ In his view, Indonesia's proto-capitalists had been largely destroyed by competition with the Dutch, meaning that Indonesian labourers were

${ }^{84}$ Ibid., p. 51. The reference to a Chinese capitalist class in Indonesia is an allusion to the fact that many businesses in the country were run by Indies Chinese. In Igog the Sarkeat Dagang Islam (Islamic Trade Union), the forerunner of the Sarekat Islam, was formed by Javanese and Arab batik dealers to protest Chinese encroachment on their industry. See Azyumardi Azra, 'The Indies Chinese and the Sarekat Islam: An Account of the Anti-Chinese Riots in Colonial Indonesia', Studia Islamika, I (April-June 1994), pp. $25^{-5}$.

${ }^{85}$ Padoman Perserikatan Kommunist India, p. 22.

${ }^{86}$ Semaoen, Penuntun Kaum Buruh, p. I2.

${ }^{87}$ Tan Malaka, Aksi Massa, pp. 26, 8. 
for the most part exploited by a foreign bourgeoisie. Using an image familiar to his audience, he wrote that 'the true Indonesian nation from the first times until now has been locked into submissive slavery, targeted by foreign robbers ... Indonesia is always the wayang [puppet], and other countries the dalang [puppeteer]. ${ }^{, 88}$ Thus, while feodalisme could be elided with keradjaan, joining Marxian and Indonesian terms, kapitalisme remained more fundamentally foreign, which facilitated the association of capitalism with imperialist exploitation.

If Indonesia lacked a strong indigenous bourgeoisie, communist publications were more certain of the presence of an Indonesian proletariat. PKI publications referred to the kaoem proletar, which was used interchangeably with kaoem koeli ('coolies'), kaoem boeroeh (workers) and kaoem Kromo (the common people). The defining quality of this group was that they owned no property of their own and so were forced to work for capitalists, who paid meagre wages. In Parlement atau Sorjet?, Tan Malaka wrote that 'The rice paddies and the fields have been leased for sugar factories, displacing thousands of the people. Thousands of the Kromo class have been forced to flee to the cities, have been forcibly enslaved [berhamba] to the sugar capitalists, forced to run to Deli, Borneo and elsewhere to get a rag of cloth and a mouthful of rice. ${ }^{89}$ Semaun likewise lamented that the classless world of the village had been replaced by a system marked by severe inequality: the owners of land, factories, and mines extracted great profits, while their workers lived in poverty and squalor. As he put it, 'the employer class alone grows richer', while 'the workers [kaum buruh] lives in poverty'. ${ }^{90}$

Like kapitalisme, the terms kaoem proletar and kaoem boeroeh helped make sense of certain facts on the ground in colonial Indonesia. Specifically, they offered a schema for understanding the growth of wage labour and labour migration which had accompanied the expansion of the country's export industries since the nineteenth century. Semarang, the strongest centre of the PKI, was itself a semi-industrial city with a busy harbour, factories, and mills. ${ }^{91}$ Its population had almost doubled since 1905, expanding from 76,413 in that year to 126,628 in $1920 .{ }^{92}$ In 1930, a fifth of the city's population worked in industry, while a further tenth

${ }^{88}$ Ibid., p. 9 .

${ }^{89}$ Tan Malaka, Parlemen Atau Soviet, p. 85.

${ }^{90}$ Semaoen, Penuntun Kaum Buruh, p. 27.

${ }^{91} \mathrm{McVey}$, The Rise of Indonesian Communism, pp. I4-15.

${ }^{92}$ A. J. Gooszen, A Demographic History of the Indonesian Archipelago, I880-1942 (Leiden: KITLV Press, I999), p. 77. 
worked in transport. Thousands were employed as workers on the docks and as day labourers unloading goods from trains. ${ }^{93}$ In this context, the notion of a proletariat dependent on capitalists for a livelihood was easily grasped.

As with feudalism and capitalism, kaoem proletar was a global category. A I923 article from Sinar Hindia claimed: 'The world is only made up of two types: oppressor and oppressed ... An elephant fears a million ants. Capitalists fear a million proletarians. ${ }^{94}$ The PKI's communist handbook reprinted Marx and Engels' call for the workers of the world to unite. ${ }^{95}$ In Parlement atau Sorjet.? Tan Malaka wrote extensively about the struggles of proletarian labourers in Britain, Austria, France, Italy, and Germany. ${ }^{96}$ These distant countries were relevant to Indonesians, he implied, because both Indonesian and European workers were members of the kaoem proletar or kaoem boeroeh and so were in engaged in a common fight against capitalism. Writing soon after his exile by the colonial government in 1922, he reflected that the Dutch had once been able to pacify rebellions in Aceh or Jambi by simply exiling rebel leaders. His own experience, however, showed that this tactic no longer worked: 'I have been exiled from the Indies by the Dutch capitalists, but I have been accepted with good cheer by the (Dutch) proletariat that is exploited and oppressed by its own people. ${ }^{97}$ Whereas once Indonesians had waged fruitless local struggles against the Dutch, they could now conceive of themselves as part of a global proletarian uprising. Such a reconceptualization could, in theory, invigorate Indonesian anti-colonial and anti-capitalist resistance by revealing it to be connected to an unstoppable international wave. As Tan Malaka put it in I922, 'across the East, with more than Iooo million people (more than $2 / 3$ of the world), there is a great movement. This great movement will not stop until all oppressors and exploiters, both foreign and internal, are burned in the fires of revolution. ${ }^{98}$

While the kaoem proletar was global, however, the kaoem Kromo remained more closely associated with Indonesia. Unlike keradjaan, it was not elevated to the status of a global category. Whereas there could be an

\footnotetext{
${ }^{93}$ Ibid., p. 78.

94 'Kommunisme dan Agama', Sinar Hindia, 3 December 1923.

${ }^{95}$ Padoman Perserikatan Kommunist India, p. I.

${ }^{96}$ Tan Malaka, Parlement Atau Soviet?, pp. 9I-96.

${ }^{97}$ Tan Malaka, Toendoek kepada kekoeasaan, p. 3I.

${ }^{98}$ Ibid., p. 30.
} 
English radja, 'Radja Jocob II' (King James II), ${ }^{99}$ there was no reference to a French or German Kromo class. The localization of Marxism thus served multiple purposes: Marxist terms could extend one's political vision, to the point where a global proletarian revolution came into view, or focus attention on the conditions within Indonesia, where the fact of the exploitation of the Indonesian Kromo by a class of wealthy, international capitalists was made clear by Marx's language of classes and capitalism.

\section{Marxism and Islam}

While Marx's class terminology encouraged Indonesians to see themselves within global categories, albeit categories that partially overlapped with Indonesian equivalents, the employment of a Muslim vocabulary brought communism into contact with another universal ideology in the form of Islam. Indonesian communists operated in a largely Islamic context and the Indonesian working class on whose behalf they claimed to be acting was made up overwhelmingly of Muslims. Shiraishi has examined the fusion of Islam and communism in the writings of Hajji Misbach, a batik dealer in Central Java, who was deeply influenced by Marx's works and was active in the Sarekat Islam in the early I920s. ${ }^{100}$ Associating Islamic communism with Misbach, however, makes this fusion appear somewhat eccentric, something present only on the fringes of Indonesian political life, rather than in the more modern, industrial centres of left-wing politics like Semarang. McVey, for example, has claimed that within the PKI there was a division between those 'on the top' who adhered to a 'proletarian scientism that one finds in Western Marxism' and 'rural adherents' who had 'very heterodox versions of the faith-particularly in the I920s, when strong Islamic communist groups existed'. ${ }^{101}$

Yet even 'orthodox', urban cadres like Tan Malaka, who were committed to 'scientific' Marxism, drew on Islam in their writings. Like many leading PKI cadres in the I920s, Tan Malaka came from what he described as a 'devout' Muslim family that 'feared Allah and followed the word of the Prophet'. ${ }^{102} \mathrm{He}$ received an elementary Islamic

\footnotetext{
99 Tan Malaka, Parlement atau Sorjet?, p. 8.

${ }^{100}$ Shiraishi, Age in Motion, pp. 285-298.

${ }^{101} \mathrm{McV}$ ey, The Social Roots of Indonesian Communism, pp. 5-6.

${ }^{102}$ Tan Malaka, Madilog: Materialisme, Dialektika, dan Logika (Yogyakarta: Penerbit Narasi, 2014), p. 479 .
} 
education in his village, which entailed the study of Arabic and the Qur'an. ${ }^{103}$ In this he was not exceptional: vernacular communist papers referred to Islam as 'our religion'; Semaun and his wife published a notice to celebrate the Islamic festival of Eid al-Fitr in I9I9. ${ }^{104}$ As already noted, the PKI operated as a bloc within Sarekat Islam during the early I920s. Semaun and Tan Malaka were prominent leaders in both organizations.

Despite their outward fidelity to Islam, members of the PKI were conscious of a potential opposition between Marxism and Islam. In I920 the Comintern condemned Pan-Islamism, and by extension all political organizations based around Islam, as reactionary, reversing their earlier attempts to win over Muslim support in Central Asia by advocating an anti-imperialist holy war. ${ }^{105}$ The non-communist Sarekat Islam press viewed Soviet Bolshevism with suspicion, and circulated stories of persecution of Muslims and Christians in Russia. ${ }^{106}$

One way of refuting the charge that communism was un-Islamic was to argue that communism, as a science, occupied a separate intellectual space to religion. As the PKI's communist handbook put it,

the other side accuse Communism of being godless. Indeed Communism does not have a God, because Communism is not a person, but a form of knowledge [pengetahoean]. Does economic science, medical science, mathematics, or agriculture have a God? Clearly not. But a communist is not hindered from honouring the name of God. The Communist Party does not ban members who honour God, they are free to follow any religion, so long as they seek revolution to bring about a communist world through the destruction of capitalism. ${ }^{107}$

In I92I, Soedibio wrote in Sinar Hindia that 'socialism means the study [pelajaran] that seeks to make property rights communal ... while religion is a study of God, according to the path of our Prophet'. Socialist science, he argued, ought to be praised by Muslims rather than seen as a threat: 'the pursuit of science [ilmoe] is not condemned by Islam, on the contrary it is required by many Muslims. ${ }^{108}$

${ }^{103}$ Ibid., p. 480.

${ }^{104}$ See 'Igama kita Islam dan pan-Islamisme', Sinar Hindia, 2 June I92I. Semaun and his wife wished the readers of Si Tetap a happy Hari Raya on 20 July igig.

${ }^{105} \mathrm{McVey}$, The Rise of Indonesian Communism, p. 54 .

106 'Communisme dan Agama', Sinar Hindia, i5 October 1923.

${ }^{107}$ Padoman Perserikatan Kommunist India, p. 50.

108 'Igama kita Islam dan pan-Islamisme', Sinar Hindia, 2 June I92I. 
Separating communism from Islam in this way presented certain problems, however, since it implied that Islam was not a central source of communist doctrine. If communism was a science, derived from the study of history and capitalism, then Islamic teachings were in a sense irrelevant to contemporary politics. In Semangat Moeda, Tan Malaka declared that the age of the Prophet offered no lessons for contemporary Indonesia, stating 'we cannot dig out ideas from more than I3oo years ago, as Haji Agus Salim believes, because society at the time had no factories, banks or railroads and was quite different from the state of our country today'. ${ }^{109}$ Indeed, he believed that Islam had even held back historical progress by helping to sustain feudal autocracies:

In order for the workers and peasants to be subject to the King [Radja] and the Nobility [Bangsawan], they must have religion, education and customs that teach of castes and servility. Churches or mosques are used by the Nobility, so that the children of the common people are taught to kneel and pray, while the children of the King and Nobles are taught to beat, curse and push aside. So it was in the Age of the Nobility in India, Java, China and Japan. ${ }^{110}$

Such a view implied not only a negative view of religion, but also a relativist one. Islam was shown by Marx's universal vision of history to be one religion among many used for the same oppressive purposes, rather than a uniquely sacred revelation.

While communists argued that communism and Islam were different types of knowledge, they nonetheless drew on an Islamic moral vocabulary in their critique of contemporary colonial capitalism. Although Tan Malaka attacked religious authorities as sustainers of feudalism, he did see value in Islamic teachings. Like other members of the PKI, he associated capitalism with nafsoe, an Arabic word connoting sinful greed or lust. In Parlement atau Sorjet?, he accused the capitalist class of acting 'for the gratification of its lust [nafsoe] for riches alone'. ${ }^{111}$ The PKI's communist handbook likewise condemned 'the greed [nafsoe] of the merchant class, who always strive to make a great profit'. ${ }^{12}$ In Tan Malaka's view Islam was naturally opposed to capitalism since it sought to suppress vicious greed: 'We know that the Prophet Muhammad SAW truly stated that the principal aspects of human nature that poison a society are the "lust [nafsoe] for power" and the

\footnotetext{
${ }^{109}$ Tan Malaka, Semangat Moeda, p. 35 .

${ }^{110}$ Ibid., p. 3 .

${ }^{111}$ Tan Malaka, Parlement atau Sorjet?, p. 92.

112 Padoman Perserikatan Kommunist India, p. I9.
} 
lust for riches. These two passions would also be eliminated by Communism through the regulations of the state. ${ }^{113}$

The view that only through communism could Islamic piety be realized was repeated in other communist publications. In an article in Sinar Hindia on 8 September 1923 Soemantri stated: 'Religion does not like to see prostitutes ... thieves and robbers etc. because these are sinful [berdosa] towards God, yet religion cannot do the slightest about the events and crimes in the world of capital, because there are indeed prostitutes, deprivation, robbery etc.- these come only from the misery of the destitute (unless indeed they are intrinsic), that is the proletariat created by the machines of capital. ${ }^{114}$ Darsono similarly claimed that, 'The rule of capital plants the seeds of wickedness [kedjahatan].' In the remnants of pre-capitalist village society, which was 'still far from the influence of capital' and did not know proletarian labour, he observed that Islamic religion remained resolute, and the sins of the capitalist world were unknown: 'In these villages, livelihood is very well ordered. The people of the village live in harmony and provide mutual help, so that there is truly real brotherhood... Where in the hearts of man there is still a strong rope of brotherhood, then mankind also is holy [suci] and faith [iman] is firm. ${ }^{115}$ In this account, communism offered an opportunity to regenerate Islam, encouraging the religious virtues of holiness (suci) and faith (iman), and the driving out of greed and individualism, the sins encouraged by capitalism. Islamic devotion alone, however, would not be enough: political organization and action was the order of the day. This reprised the communist critique of mysticism or kebatinan, which focused primarily on internal improvement while ignoring the external world (lahir).

In this vein, Partondo wrote in his introduction to his translation of The Communist Manifesto,

We hope for the coming of a world that is constituted on purity. People on the other side, that is the side that is not communist, especially the capitalist class, say that society cannot be made good and pure, if humanity remains wicked [djahat $]$ in its behaviour... Our outlook on these matters is entirely the reverse. Mankind cannot become good in its behaviour, if the constitution of society is not perfected. So to improve the world, first the state of society must be perfected. ${ }^{116}$

${ }^{113}$ Tan Malaka, Parlement atau Sovjet?, p. 78.

114 'Islam sebagai dasar pergerakan Ra'jat dalam doenia kapitaal', Sinar Hindia, 8 September 1923 .

${ }^{115}$ Darsono, 'Kommunisma dan Islamisma', Sinar Hindia, I5 February I921.

${ }^{116}$ Partondo, Manifest kommunist, p. I. 
Communism, then, was a means to perfect Islam; inward-looking Islamic piety in itself would be insufficient.

If communism was necessary to create a world where Islam could flourish, PKI members also claimed that the political struggle to create a communist society was itself a form of Muslim piety. Semaun's model political leader strongly resembled an Islamic ascetic and holy man:

They must become an example of goodness, fidelity, strength and boldness in their actions. They must sacrifice themselves for the good of the oppressed, those exploited, and also always move towards dignified tasks. Although there are many obstacles, troubles and difficulties ... Do not expect payment, praise and worldly things ... let them wear the maxim: 'With Lord Allah for Lord Allah' ... A leader does not obtain worldly things, in the time he lives in the world, but must look to the afterlife (a later day), after he has died. This is testament to his strength as a leader. ${ }^{117}$

The 1926 pamphlet The Peasants' Movement in Indonesia, written in English by Iwa Koesoemasoemantri under the pseudonym S. Dingley, stated that the PKI used the Qur'anic story of Moses's resistance of the Pharaoh as a way to incite rebellion against the Dutch, again suggesting that active resistance of existing powers was a form of conduct sanctioned by Islam. ${ }^{118}$

Tan Malaka also saw Islamic holy figures as models for communist leadership. In Parlement atau Sorjet?, he likened the Bolsheviks to religious prophets:

the history of the world shows that something which contains the truth will inevitably rise, regardless of obstacles and enemies, no matter how much of the Bolsheviks' propaganda was suppressed during the reign of the Tsar, no matter how much suffering Trotsky and Lenin experienced, their sacred ideals inevitably radiated their light. Do we forget the misery and humiliation that was suffered by the Prophet Muhammad in the ten years before he came to Medina? Have we forgotten that 2000 years ago, the truth of the Christian religion had to be paid for by the Prophet Jesus with his blood and his life? Have not all prophets started out small, then after tens, even hundreds of years, become important? ${ }^{119}$

This quotation is noteworthy for two reasons. First, because it seems to accept the validity of the Christian teaching that Jesus died during his

117 Semaoen, Penuntun Kaum Buruh, pp. 105-106.

${ }^{118}$ S. Dingley [Iwa Kusumasumantri], The Peasants' Movement in Indonesia (Berlin: n.p., n.d. [I926]), p. 49 .

${ }^{119}$ Tan Malaka, Parlement atau Sorjet?, p. 68. 
crucifixion, a point denied in orthodox Islamic theology, which claims that Jesus was replaced on the cross and so did not pay with his 'blood and his life'. This suggests that while Tan Malaka continued to use Islamic terms, his understanding of religion had become blurred between Christian and Islamic teaching, perhaps unsurprisingly given that his youth had been divided between West Sumatra and the Netherlands. The second significant aspect of this quotation is that it implied that communism was a type of religious movement, like Islam and Christianity, with a providential historical destiny that made its triumph inevitable. As such, it was not comparable to other political revolutions. For all his historical materialism, Tan Malaka at times conceived of communism as a kind of transcendent ideal, which depended for its success on the righteousness of its principles rather than on any material or historical contingency.

By employing Islamic terms and concepts, Indonesian communists were able to portray capitalism not only as exploitative but also as sinful. Communism, meanwhile, could be framed both as a doctrine based on scientific observation and a moral and religious uprising, to the point where Lenin could be seen as a worthy successor to Muhammad. The ease with which communists turned to an Islamic vocabulary suggests they did not see a fundamental conflict between Marxism and Islam. Rather, they understood Marxism in part through the Islamic idiom, with which both they and their audience were familiar, just as they saw Islam through the lens of Marxist notions of anti-capitalist revolutionary struggle and communist egalitarianism.

\section{Conclusion: retranslating Marxism}

Surveying Indonesian communist publications from I9I4 to I927 reveals a blending of foreign and indigenous terms, a combination of words and concepts with global and local circulations. A Dutch and transliterated Marxist terminology was used in the writings of PKI members to demonstrate their mastery of modern science, to help explain contemporary social and economic change in Indonesia, and to encourage Indonesians to imagine themselves as part of a worldwide struggle against capitalism. The concurrent use of Malay social terminology allowed communists to ground the language of Marx in Indonesian society and history, while simultaneously extending Indonesian social terms to the status of universal categories. The 
selective use of an Islamic vocabulary, meanwhile, helped to make communism more easily comprehensible for Indonesian Muslims and added a moral dimension to the Marxist critique of capitalism. The striking linguistic eclecticism of communist writings was mirrored by the diversity of symbols used by the PKI in its early years: the party's I92I congress, held on Christmas Day, took place against a backdrop of portraits of Marx, Rosa Luxemburg, Karl Liebknecht, Lenin, and Trotsky, as well as images of the Indonesian anti-colonial rebels Sentot, Diponegoro, and Kyai Madja. ${ }^{120}$

This breadth demonstrates a more general intellectual variety in Indonesian society during the early twentieth century. Shiraishi has characterized this as an 'age in motion' not only because it was the age of political change, triggered by the nascent anti-colonial national movement, but also because it was a time when new ideas circulated rapidly through the Indies, where they were combined in original ways, without solidifying into the unitary and opposed categories of Islam, nationalism, and communism that characterized the post-revolutionary political landscape of the Indonesian Republic. As we have seen, communism was at times held up as a political language independent of Indonesian political thought, which could be used to reform Indonesian politics, but was also enmeshed with existing political and religious vocabularies, to the point where it is hard to say where local and Islamic idioms end and Marxism begins.

As Henk Schulte Nordholt and Tom Hoogervorst have argued, in the early twentieth century, hybrid lifestyles were emerging in Indonesia, especially among the educated urban middle class, who consumed American, Japanese, and European goods, and whose taste in films, music, and literature was increasingly international. ${ }^{121}$ Indonesians were also consuming political ideas from across the world in the Igros and I920s, and fusing them in new and original ways, creating a multilingual political style. Rather than seeing this as an example of complete 'localization', in Wolters' terms, or as the absorption of Indonesians into a universal world culture, as Anderson has argued, we should instead envision this process as a dialogue between foreign and

${ }^{120} \mathrm{McVey}$, The Rise of Indonesian Communism, pp. I13-1 I4.

${ }^{121}$ Tom Hoogervorst and Henk Schulte Nordholt, 'Urban Middle Classes in Colonial Java (1900-1942): Images and Language', Fournal of the Humanities and Social Sciences of Southeast Asia, I73 (2017), pp. $44^{2-474}$, at p. 444 . 
indigenous, sometimes in tension, sometimes smoothly flowing together. For a time, Marx and Diponegoro stood side by side.

From the mid-ig20s, however, there was a discernible shift away from this hybrid political language, towards a seemingly more Indonesian political lexicon. Communists had always been vulnerable to the charge that they were out of touch, since they made use of a theoretical Marxist vocabulary that was foreign to the Indonesian workers they claimed to represent. They could also be accused of lacking patriotism because, despite their claims of fighting on behalf of the Indonesian masses, they were liable to be portrayed as putting the interests of the global class struggle above those of their own nation. A 1925 article on Tan Malaka in the Sarekat Islam paper Hindia Baroe called him an 'internationalist', which the author defined as 'one who does not love his own country and nation'. ${ }^{122}$

This was a line of criticism taken seriously by Sukarno, who began his career as a nationalist politician in the mid-I920s, as the PKI was moving in an increasingly radical and revolutionary direction. In his famous I926 essay 'Nationalisme, Islamisme dan Marxisme' ('Nationalism, Islamism and Marxism'), published in the paper Soeloeh Indonesia Moeda ('Torch of Young Indonesians'), he argued that the internationalist and secular leanings of some communists were counterproductive and even elitist. Communists had a tendency to quote Marx and Engels to justify their views rather than speaking in a way that showed sympathy with the beliefs of their fellow Indonesians. ${ }^{123}$ The result, he claimed, was that they undervalued nationalism and Islam: 'Marxists who still persist in animosity towards the strong Nationalist and Muslim movements in Asia, such Marxists fail to keep with the times. ${ }^{124}$ While he believed that Marxism was a useful tool of economic analysis and had galvanized a strong and progressive anti-capitalist movement in the West, he considered Marxist terms to be of limited applicability in 'the countries of Asia where there is as yet no proletariat in the sense pertaining in Europe or America'. ${ }^{125}$

For Sukarno, then, Marxism was not a universal science which could exist alongside prevailing Indonesian and Islamic political idioms but an inescapably Western form of social analysis. What was required was a

\footnotetext{
122 'Tan Malaka dan Partijnja', Hindia Baroe, io January i925.

${ }^{123}$ Soekarno, Under the Banner of Revolution, Vol. I, p. I6.

${ }^{124}$ Ibid., p. I7.

${ }^{125}$ Ibid., pp. I8-19.
} 
more completely Indonesian political vocabulary or class, shorn of its transliterated Marxist terminology. In I933, as the leader of the nationalist Partindo party, he argued that henceforth Marhaen, a name he invented for a fictitious Indonesian peasant, should be used in place of proletar. ${ }^{126}$ He preferred Marhaen to proletarian because it was a more expansive word, in that it included peasants and small traders as well as industrial labourers, making it more applicable to rural Indonesia. Marhaen was also nationally specific. While there could be a British proletariat or an American working class, Marhaen referred only to Indonesians, which made it a readier fit with Sukarno's nationalist rhetoric than the suspiciously foreign-sounding 'proletariat'.

As we have seen, however, in the rgros and I920s, Indonesian communists were also at pains to find Indonesian equivalents for Marx's class terminology, such as boeroeh (worker), Kromo (common people), and Ningrat (aristocracy). This shows that Sukarno's characterization of them as entirely reliant on Marx and Engels is misleading. It is true, though, that members of the PKI did see Marxian terms as, in some sense, indispensable, which is why they continued to use them in a transliterated form. Marx's categories could be scaled up to a global level, bringing a worldwide class struggle into view, and offered a seemingly universal and 'scientific' means of describing the economic realities of class in contemporary and historical Indonesia. Sukarno, by contrast, believed that the term 'proletariat' could be entirely replaced with Marhaen, implying that he saw the international class struggle and a strictly Marxian scheme of social classification as less useful than the communists.

During the Indonesian revolution (I945-49), Tan Malaka, having reappeared in I945 after 20 years of exile and life underground, coined a new class term himself: moerba (the lowly), which included factory workers, peasants, transport workers, the urban poor, and even intellectuals. $^{127}$ Like Marhaen and Kromo, this class constituted the majority of Indonesian society and was nationally specific. As with those terms, moerba was explicitly described as a means of overcoming Marx's terminology. As Tan Malaka put it in 1948, the moerba 'more or less approximates proletariat' but was fundamentally different from 'the Western proletariat in Europe and America' because of Indonesia's

\footnotetext{
${ }^{126}$ Ibid., pp. $24 \mathrm{I}-244$, at p. $24 \mathrm{I}$.

127 Tan Malaka, From fail to Fail, p. xci.
} 
unique historical development. ${ }^{128}$ In contrast with his first Malay translations of Marx's terms in the I920s, by the I940s Tan Malaka, like Sukarno, worked on the assumption that a transliterated Marxist terminology could not be combined with an existing Indonesian language of class, in a manner that integrated the struggle of Indonesian workers with a global class war, but needed to be replaced with a new vocabulary that expressed the distinctive characteristics of Indonesian society and pulled loose of its Marxian moorings. Translation, in this view, was used instead of transliteration rather than alongside it.

The irony, though, was that the starting point for Tan Malaka and Sukarno's new class classification was Marx's own thought. Indeed, neither could ever entirely escape Marx's categories. Tan Malaka felt obliged to explain the relationship of moerba to the proletariat, while Sukarno insisted that Marhaen subsumed the proletariat, which he still considered a recognizable social group, being 'the direct product of capitalism and imperialism', that would have a 'very large part indeed' in the struggle of the Marhaen. ${ }^{129}$ Even in its absence, then, Marxism continued to haunt Indonesian political thought in the I93os and the I940s, because Marxist concepts provided the framework within which both Sukarno and Tan Malaka developed their neologisms for the Indonesian masses. Intellectual cosmopolitanism, though partly concealed, remained essential. The initial contact with Marx, made in the IgIos and I920s, proved hard to move beyond. The spectre of communism could not be exorcised.

128 Translation by Helen Jarvis, quoted in Tan Malaka, From Fail to Fail, p. xci.

${ }^{129}$ Soekarno, Under the Banner of Revolution, Vol. I, pp. 24I-242. 